\title{
Wild fish are negligible transmitters of viral haemorrhagic septicaemia virus (VHSV) genotype Id in the VHS restriction zone in Finland
}

\author{
Pia Vennerström ${ }^{1, *}$, Elina Välimäki ${ }^{1}$, Maria Hautaniemi ${ }^{2}$, Tapani Lyytikäinen ${ }^{3}$, \\ Suvi Kapiainen ${ }^{1}$, Gabriele Vidgren ${ }^{4}$, Anna-Maija Virtala ${ }^{5}$ \\ ${ }^{1}$ Production Animal and Wildlife Health Research Unit, Finnish Food Safety Authority, 00790 Helsinki, Finland \\ ${ }^{2}$ Virology Research Unit, Finnish Food Safety Authority, 00790 Helsinki, Finland \\ ${ }^{3}$ Risk Assessment Research Unit, Finnish Food Safety Authority, 00790 Helsinki, Finland \\ ${ }^{4}$ Department of Pathology, Finnish Food Safety Authority, 00790 Helsinki, Finland \\ ${ }^{5}$ Department of Veterinary Biosciences, Faculty of Veterinary Medicine, University of Helsinki, \\ 00014 University of Helsinki, Finland
}

\begin{abstract}
Wild fish were suspected to be the source of reinfection by viral haemorrhagic septicaemia virus (VHSV) in Finnish brackish water rainbow trout farms located in a restriction zone regarding viral haemorrhagic septicaemia (VHS) comprising the entire Province of Åland, Baltic Sea, in the 2000s. Altogether, 1636 wild fish of 17 different species living in the vicinity of infected fish farms were screened for VHSV during the years 2005-2008. Additionally, 2 uninfected wild fish species as well as farmed whitefish were introduced into a VHS-positive fish farm to test whether they became infected by VHSV from the clinically diseased rainbow trout. Wild fish did not test positive for VHSV on any occasion. In contrast, whitefish introduced to a VHS-positive farm were infected with VHSV genotype Id and started to replicate the virus for a short time during the trial. Whitefish are farmed together with, or in the vicinity of, farmed rainbow trout in the study area and, according to this study, are a possible source of the recurring infection in the restriction area. A sprivivirus was isolated from all fish species in the infection trial without causing mortality in the test groups.
\end{abstract}

KEY WORDS: Viral hemorrhagic septicemia - VHSV - Aquaculture - Disease control · Whitefish · Wild fish · Carrier · Epidemiology

\section{INTRODUCTION}

Viral haemorrhagic septicaemia viruses (VHSVs) are a group of novirhabdoviruses that has been isolated from a wide range of wild and farmed fish species in Europe, North America and Japan living in both marine and freshwater (review by Skall et al. 2005, Elsayed et al. 2006, Lumsden et al. 2007, Dale et al. 2009, Bain et al. 2010, Gadd et al. 2010, 2011, Kim \& Faisal 2010, Emmenegger et al. 2013, Ito \& Olesen 2013, OIE 2017). VHSV is a negativestranded RNA virus of which isolates cluster into 4

*Corresponding author: pia.vennerstrom@evira.fi different genotypes (I-IV), with several subtypes in genotypes I (Ia-Ie) and IV (IVa-IVd) (Snow et al. 1999, Einer-Jensen et al. 2005, Elsayed et al. 2006, Ammayappan \& Vakharia 2009, Pierce \& Stepien 2012, Cuenca et al. 2017). The genotypes are generally more tied to geographical region than to target species (Snow et al. 1999, Nishizawa et al. 2002, Thiery et al. 2002, Einer-Jensen et al. 2004).

According to phylogenetic studies, VHSV has its ancestors in the marine environment, from where it has adapted to be a serious disease agent for farmed rainbow trout Oncorhynchus mykiss (Einer-Jensen et

() The authors 2018. Open Access under Creative Commons by Attribution Licence. Use, distribution and reproduction are unrestricted. Authors and original publication must be credited. 
al. 2004). The 'change in host range' has probably happened several times since the first reports of clinical outbreaks of viral haemorrhagic septicaemia (VHS) originating from the 1950s (Einer-Jensen et al. 2004). These historical leaps over the species barriers are likely, at least in large part, attributed to human activities in connection with fish farming procedures and virus adaptation to new hosts. Wild marine fish, mainly herring Clupea harengus, were intensively used as minced fresh feed for freshwater farmed rainbow trout in Europe in the 1950s (Meyers \& Winton 1995, Dixon 1999, Einer-Jensen et al. 2004). The use of fresh marine fish as a source of feed decreased throughout Europe when several wild marine fish species, including herring, were identified as carriers of VHSV and it was found that VHSV could be spread by the oral route (Stone et al. 1997, Snow et al. 1999, Mortensen et al. 1999). VHSV types pathogenic to rainbow trout have been isolated from marine wild fish in Europe on some occasions, but no mass mortality or clinical signs of VHS have been reported in these wild fish species (Skall et al. 2005). In contrast, in North America, mortalities due to infections with VHSV have been reported on several occasions in wild fish (Marty et al. 1998, Meyers et al. 1999, Elsayed et al. 2006, Gagné et al. 2007, Groocock et al. 2007, Lumsden et al. 2007, Ammayappan \& Vakharia 2009).

In Finland, VHS has been reported in 3 separate fish farming locations on the south and southwest coasts during 2000-2012 (Raja-Halli et al. 2006). VHS was first isolated in 2000 on the southwest coast of Finland in the Province of Åland and a few weeks later on the south coast. VHSV was isolated at a third location also on the west coast in 2003 and again in 2008 (Raja-Halli et al. 2006, Finnish Food Safety Authority 2010). Mortalities in these disease outbreaks have varied from negligible up to $50 \%$ on some occasions. VHS in fish farms in 2 of these areas has been successfully eradicated, but the area where VHS was first recorded in the Province of Åland is still classified as VHS-positive. A common source of the outbreaks in Finnish fish farms is suspected as all of the VHSV isolates were genotype Id and, according to sequencing results, almost identical (RajaHalli et al. 2006). The source of the first VHS outbreak in Finland is still unknown, but wild fish, mainly herring, are considered to be the most likely source of infection since VHSV genotype Id (hereafter VHSV Id) is genetically close to isolates from wild fish and early Danish isolates from farmed rainbow trout (Skall et al. 2004). Further evidence supporting herring as a likely source is the fact that wild herring had previously been used as minced fresh feed in some fish farms in this area (Raja-Halli et al. 2006).

Wild salmonid brood fish, Baltic herring Clupea harengus membras and lamprey Lampetra fluviatilis have been screened for VHSV in the same parts of the Baltic Sea where these VHSV-positive Finnish fish farms are located, but VHSV Id has not been isolated from wild fish. Nonetheless, Baltic herring and lamprey were found to be carriers of VHSV genotype II (Gadd et al. 2010, 2011). The highest prevalence of VHSV II, 50 of 479 pools (10.4\%), was recorded in herring originating from the Archipelago Sea southwest of Finland (Gadd et al. 2011). However, VHS has never been recorded in farmed fish in this area even though intensive fish farming has been performed for decades and minced wild herring was previously used as fresh feed. According to the infection trials, the pathogenicity of the isolated VHSV II strains to rainbow trout was negligible (Gadd et al. 2011).

The aim of the present study was to survey whether wild fish living in close proximity to the net pens in VHSV-positive fish farms could be carriers of this virus. Additionally, the aim was to study under field conditions whether VHSV Id can be naturally transmitted to perch Perca fluviatilis, roach Rutilus rutilus and whitefish Coregonus lavaretus from clinically diseased farmed rainbow trout in a VHSV-positive fish farm.

\section{MATERIALS AND METHODS}

\section{Collection of wild fish for virus examination}

Wild fish were caught in the immediate vicinity of 2 VHSV-positive food fish farms that were farming rainbow trout in the brackish sea area in the Baltic Sea; fish were caught beside, between and under the net pens. The farms are situated in the Province of Åland, in a VHS restriction zone that was established in 2001 after VHSV was detected in several farms (Raja-Halli et al. 2006). The fish were caught with 2 specially designed nets with 4 different mesh sizes $(10,20,30$ and $40 \mathrm{~mm})$ on 12 different occasions: once in autumn 2005, 6 times in spring 2006, 3 times in autumn 2006, once in spring 2007 and once in autumn 2008. The nets were set in the water in the vicinity of the net pens in the evening and kept in place overnight before they were pulled up from the water and emptied of fish. Species caught and the number of different species tested are presented in 
Table 1. Rainbow trout in both farms in the restriction zone tested VHSV-positive on several occasions before the sampling, and on 2 occasions in spring 2006 the sampling was performed during a clinical VHS outbreak on the nearby fish farm. All caught wild fish were tested, unless over 100 fish per species were caught, in which case only 100 fish of those species were collected non-randomly for testing. Tissue samples from the anterior kidney, spleen, brain and heart were taken and samples from a maximum of 5 fish were pooled together. Fish species that rapidly decompose due to high fat content, such as herring and sprat, were sampled immediately after capture, and the rest of the fish were iced and transported to the laboratory for further sampling. All tissue samples were obtained and appropriately preserved within $1 \mathrm{~d}$ of capture. The water temperature ranged from $2^{\circ} \mathrm{C}$ to $13^{\circ} \mathrm{C}$ during the sampling.

Table 1. Laboratory results for surveillance of viral haemorrhagic septicaemia virus (VHSV) for 17 wild fish species in the vicinity of 2 VHSVpositive fish farms in the viral haemorrhagic septicaemia restriction zone of the Province of Åland, in the Baltic Sea, during $2005-2008$. qRT-PCR: real-time reverse transcription PCR; PS: positive strand; NS: negative strand; nd: not determined; CI: confidence interval

\begin{tabular}{|c|c|c|c|c|c|c|c|c|c|c|}
\hline \multirow[t]{2}{*}{ Fish species } & \multicolumn{4}{|c|}{ Number of fish sampled } & \multicolumn{4}{|c|}{ — Results for laboratory examinations -} & \multicolumn{2}{|c|}{ — Prevalence $(\%)$} \\
\hline & Autumn & Spring & Total & $\begin{array}{l}\text { Percent- } \\
\text { age }\end{array}$ & $\begin{array}{l}\text { Virus } \\
\text { isolation }\end{array}$ & qRT-PCR & $\begin{array}{l}\text { PS qRT- } \\
\text { PCR }\end{array}$ & $\begin{array}{l}\text { NS } \\
\text { qRT-PCR }\end{array}$ & $\begin{array}{l}\text { Ob- } \\
\text { served }\end{array}$ & $\begin{array}{l}\text { Median } \\
\text { estimate } \\
(95 \% \text { CI })\end{array}$ \\
\hline $\begin{array}{l}\text { Perch } \\
\text { Perca fluviatilis }\end{array}$ & 300 & 213 & 513 & 31.36 & Negative & Negative & nd & nd & 0 & $0.04(0-0.49)$ \\
\hline $\begin{array}{l}\text { Bleak } \\
\text { Alburnus alburnus }\end{array}$ & 70 & 329 & 399 & 24.39 & Negative & Negative & nd & nd & 0 & $0.06(0-0.63)$ \\
\hline $\begin{array}{l}\text { Roach } \\
\text { Rutilus rutilus }\end{array}$ & 168 & 97 & 265 & 16.20 & Negative & Negative & nd & nd & 0 & $0.09(0-0.94)$ \\
\hline $\begin{array}{l}\text { Three-spined stickleback } \\
\text { Gasterosteus aculeatus }\end{array}$ & 2 & 151 & 153 & 9.35 & Negative & Negative & nd & nd & 0 & $0.15(0-1.63)$ \\
\hline $\begin{array}{l}\text { Ruffe } \\
\text { Gymnocephalus cernuus }\end{array}$ & 0 & 87 & 87 & 5.32 & Negative & Negative $^{a}$ & Negative & Negative $^{a}$ & 0 & $0.26(0-2.84)$ \\
\hline $\begin{array}{l}\text { Herring } \\
\text { Clupea harengus membras }\end{array}$ & 30 & 46 & 76 & 4.65 & Negative & Negative $^{\mathrm{b}}$ & Negative & Negative & 0 & $0.30(0-3.27)$ \\
\hline $\begin{array}{l}\text { White bream } \\
\text { Abramis bjoerkna }\end{array}$ & 30 & 36 & 66 & 4.03 & Negative & Negative & nd & nd & 0 & $0.75(0-3.72)$ \\
\hline $\begin{array}{l}\text { Smelt } \\
\text { Osmerus eperlanus }\end{array}$ & 0 & 32 & 32 & 1.96 & Negative & Negative & nd & nd & 0 & $1.51(0-7.49)$ \\
\hline $\begin{array}{l}\text { Rudd } \\
\text { Scardinius erythrophthalmus }\end{array}$ & 4 & 16 & 20 & 1.22 & Negative & Negative & nd & nd & 0 & $1.12(0-11.66)$ \\
\hline $\begin{array}{l}\text { Rainbow trout } \\
\text { Oncorhynchus mykiss }\end{array}$ & 1 & 6 & 7 & 0.43 & Negative & Negative $^{c}$ & Negative & Negative & 0 & $3.09(0-29.24)$ \\
\hline $\begin{array}{l}\text { Fourhorn sculpin } \\
\text { Triglopsis quadricornis }\end{array}$ & 2 & 4 & 6 & 0.37 & Negative & Negative $^{\mathrm{d}}$ & nd & nd & 0 & $3.57(0-33.04)$ \\
\hline $\begin{array}{l}\text { Flounder } \\
\text { Platichthys flesus }\end{array}$ & 1 & 4 & 5 & 0.31 & Negative & Negative & nd & nd & 0 & $4.23(0-37.94)$ \\
\hline $\begin{array}{l}\text { Sea trout } \\
\text { Salmo trutta }\end{array}$ & 0 & 2 & 2 & 0.12 & Negative & Negative & nd & nd & 0 & $9.55(0-66.68)$ \\
\hline $\begin{array}{l}\text { Straight-nosed pipefish } \\
\text { Nerophis ophidion }\end{array}$ & 2 & 0 & 2 & 0.12 & Negative & Negative & nd & nd & 0 & $9.55(0-66.68)$ \\
\hline $\begin{array}{l}\text { Eelpout } \\
\text { Zoarces viviparus }\end{array}$ & 0 & 1 & 1 & 0.06 & Negative & Negative & nd & nd & 0 & $16.3(0-85.33)$ \\
\hline $\begin{array}{l}\text { Ide } \\
\text { Leuciscus idus }\end{array}$ & 1 & 0 & 1 & 0.06 & Negative & Negative & nd & nd & 0 & $16.3(0-85.33)$ \\
\hline $\begin{array}{l}\text { Pike } \\
\text { Esox lucius }\end{array}$ & 0 & 1 & 1 & 0.06 & Negative & Negative & nd & nd & 0 & $16.3(0-85.33)$ \\
\hline Total & 611 & 1025 & 1636 & 100.00 & & & & & & \\
\hline
\end{tabular}




\section{Infection trial in field conditions}

Altogether, 500 wild perch Perca fluviatilis and roach Rutilus rutilus were caught with a bow net on the southwest coast of Finland, outside the VHS restriction zone. To determine whether the wild-caught fish were free of VHSV, control samples of 100 fish of each species were non-randomly collected with a dip net for virus testing. Of each species, 150 live fish were transported in $1500 \mathrm{l}$ aerated transport tanks to a VHSV-positive fish farm in the VHS restriction zone in the Province of Aland. Additionally, 150 whitefish from a fish farm in the VHS-free continental zone in Finland were transported in the same way to the same farm. Control samples of 40 whitefish were collected non-randomly with a dip net for virus testing before transport. The fish were placed in 9 small net cages, with 50 fish in each cage and 3 cages per species. The test cages were placed beside the sea cages where clinical VHS had been confirmed in rainbow trout $1 \mathrm{wk}$ earlier. Fifty fish of each species functioned as control groups in similar cages but at another fish farm in the sea area outside the VHS restriction zone. The fish were inspected every day and 10 fish per cage were collected for sampling on Days 10, 14, 21 and 35 after the transfer (Table 2). Fish with any signs of disease or that were in poor condition were first selected for sampling; otherwise, fish were picked non-randomly with a dip net for sampling. The rainbow trout at the farms were also tested for VHSV on Days 0, 10 and 14. After Day 14, the rainbow trout in the farm were moved to a nearby summer farming site and only the test cages were left on the farm.

All fish that were collected for testing for the presence of VHSV were transported on ice to the laboratory and sampled the next day. Tissue samples from the brain, spleen, heart and anterior kidney of 5 fish from the same cage were pooled together (2 pools per cage). Samples from the gills and skin were also collected from these fish and pooled in 2 separate tissue pools per cage. The control cages at the control

Table 2. Results from the infection trial performed to reveal whether wild perch, roach and farmed whitefish could be infected by viral haemorrhagic septicaemia virus (VHSV) in field conditions at a VHSV-positive fish farm in the viral haemorrhagic septicaemia restriction zone of the Province of Åland in the Baltic Sea. qRT-PCR: real-time reverse transcription PCR; PS: positive strand; NS: negative strand; nd: not determined. VHSV-positive pools are highlighted in bold

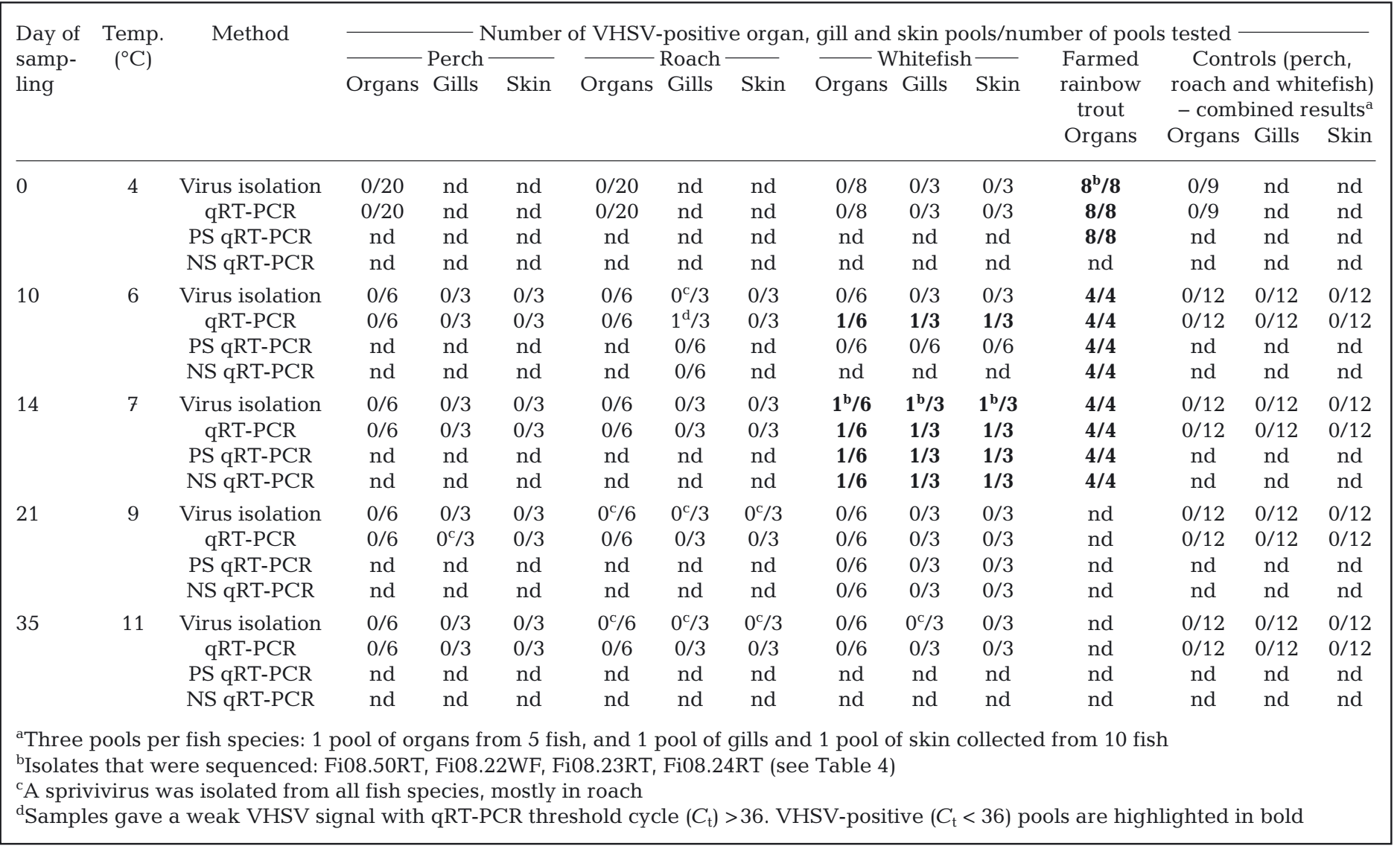


farm were inspected and sampled likewise. The sampling regime is presented in Table 2 .

\section{Virus isolation}

Tissue samples of the brain, spleen, heart and anterior kidney from wild fish and fish from the infection trial were examined for the presence of VHSV according to EU Commission Decision 2001/183/EEC (EC 2001) (see Tables 1 \& 2). Organ samples from a maximum of 5 fish were pooled in 9 volumes of cell culture medium (Eagle's minimum essential medium, Gibco, and $10 \%$ fetal bovine serum, pH 7.4) containing penicillin and streptomycin. Gill and skin samples were examined separately in pools consisting of 10 fish. All samples were homogenized and centrifuged (15 min at $4000 \times g, 4^{\circ} \mathrm{C}$ ), and each organ pool was treated separately to avoid contamination between samples. The supernatant was collected for immediate inoculation into 24-well tissue culture plates (Nunc) with monolayer cell cultures of bluegill fry (BF-2) fibroblasts and epithelioma papulosum cyprinid (EPC) epithelial cells (Olesen \& Jørgensen 1992). The samples were inoculated in BF-2 and EPC cells no later than $24 \mathrm{~h}$ post euthanasia. All samples were incubated in 2 passages for a total of at least $14 \mathrm{~d}$. Isolated virus strains were confirmed to be VHSV with a commercial ELISA kit according to the manufacturer's instructions (TestLine) and some isolates of VHSV were confirmed with additional sequencing.

\section{Real-time RT-PCR for examining the presence of VHSV from tissue suspensions}

One microlitre of the same tissue suspension that was used for virus isolation was frozen in $-80^{\circ} \mathrm{C}$ to be later tested with a real-time reverse transcription polymerase chain reaction (qRT-PCR) (later called diagnostic qRT-PCR). RNA extraction was carried out using an RNeasy Mini Kit (Qiagen), and qRT-PCR was performed with a QuantiTect Probe RT-PCR Kit (Qiagen) according to the manufacturer's instructions. The final concentrations of the primers and probe were 300 and $100 \mathrm{nM}$, respectively. The reverse transcription reaction profile was $30 \mathrm{~min}$ at $50^{\circ} \mathrm{C}$ and $15 \mathrm{~min}$ at $95^{\circ} \mathrm{C}$; followed by 50 cycles of $15 \mathrm{~s}$ at $95^{\circ} \mathrm{C}$ and $1 \mathrm{~min}$ at $60^{\circ} \mathrm{C}$.

The primers and the probe (Med Probe) for the diagnostic qRT-PCR were manufactured according to the VHSV N gene sequence from GenBank accession number D00687 after Chico et al. (2006). The probe was 5'-end labelled with FAM and 3'-end labelled with TAMRA (Table 3). We used a threshold cycle $\left(C_{t}\right)$ cut-off value of 36 as estimated in our earlier study (Vennerström et al. 2017).

\section{Strand-specific qRT-PCR}

As sampling was performed in an environment assumed to be highly contaminated by VHSV, a new qRT-PCR method (hereafter, strand-specific qRTPCR) was developed to test for negative and positive stranded VHSV products formed during VHSV replication. This method could be used to rule out possible environmental virus contamination and to test whether the virus was actively replicating in the tested fish tissues. This strand-specific qRT-PCR method is based on a method previously described by Purcell et al. (2006). Controls for the strandspecific method were created with in vitro transcription from cloned VHSV N gene amplicons. Primers and probes used are presented in Table 3.

\section{Cloning of PCR product for in vitro transcription}

To create a template for positive and negative control RNA, an 810 bp amplicon from VHSV N gene PCR was inserted into a pSC-A plasmid and transfected into StrataClone SoloPack competent cells (StrataClone ${ }^{\mathrm{TM}}$ PCR Cloning Kit, Stratagene) according to the manufacturer's instructions. The resulting plasmids were purified with a QIAprep Spin Miniprep Kit (Qiagen) and verified by restriction digestion and sequencing with the universal T3 and T7 primers. Sequencing was performed by the Institute of Biotechnology, University of Helsinki, Finland.

\section{In vitro transcription}

The control RNA for strand-specific qRT-PCR was prepared in 2 separate in vitro transcription reactions to produce both positive and negative strand RNA. Based on sequencing, the orientation of the insert could be determined, and linearization of the plasmid was performed with BamHI (Fermentas) or HindIII (Fermentas) for positive- or negative-strand RNA transcription, respectively.

In vitro transcription of linearized plasmids was performed with a MAXIscript T7/T3 Transcription Kit (Ambion, Applied Biosystems) according to the manufacturer's instructions. Both positive- and negative- 


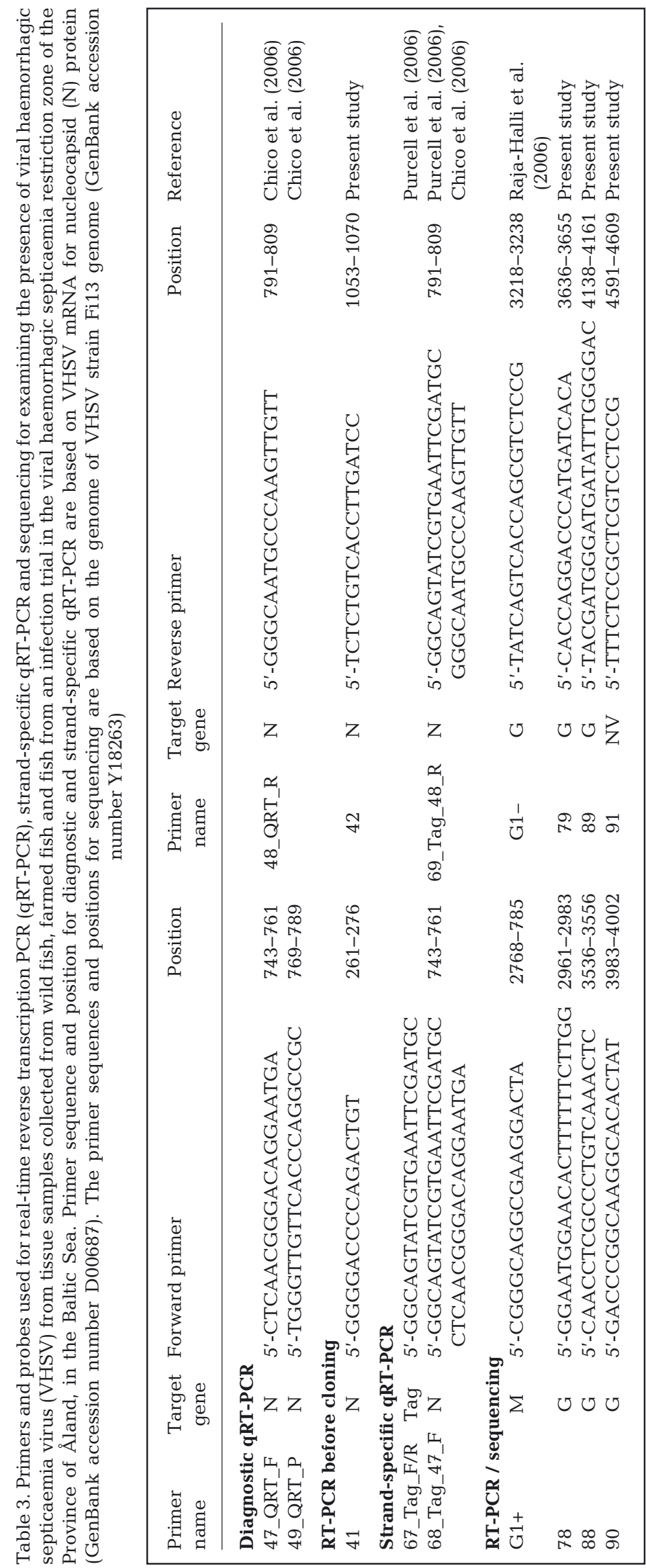

strand RNA concentrations were adjusted to $200 \mathrm{ng} \mathrm{ll}^{-1}$, and the RNA was aliquoted and stored at $-70^{\circ} \mathrm{C}$.

$$
\begin{aligned}
& \text { Positive- and negative-strand } \\
& \text { qRT-PCR/cDNA synthesis and } \\
& \text { reverse transcription }
\end{aligned}
$$

For the detection of positive-stranded RNA, we isolated $0.5-2 \mu \mathrm{g}$ of total RNA from fish organ pools using an RNeasy Mini Kit. Reverse transcription was performed according to Purcell et al. (2006) and Chico et al. (2006). Tagged antisense primer (reverse) was used to synthesize positivestrand-based cDNA and tagged sense primer (forward) to synthesize negativestrand-based cDNA. The VHS tagged and sequence-specific PCR primers (Med Probe) are listed in Table 3.

\section{Sequencing of isolated VHSV strains}

To determine the genotype of the VHSV strains, the complete sequence of the glycoprotein (G) gene of 3 rainbow trout and 3 whitefish VHSV isolates (Table 4) were amplified in 4 separate RT-PCR reactions per isolate and the amplicons were sequenced with primers used in the PCRs. RT-PCR amplifications were performed as described in Raja-Halli et al. (2006). Primer sequences (Table 3) targeting VHSV G, matrix (M) and non-structural (NV) gene regions were based on the published genome of VHSV strain Fi13 (GenBank accession number Y18263.1; Schutze et al. 1999).

Sequencing reactions were performed using BigDye v.3.1 chemistry (Applied Biosystems) and the reactions were run on an ABI 3100-Avant genetic analyser. For each sample, the individual PCR sequences were edited and assembled into contigs using Lasergene SeqMan Pro version 8.0.2 (DNASTAR). The assembled sequences were aligned with $G$ gene sequences of selected Finnish and other VHSV isolates belonging to genotypes I-IV (Table 4) using ClustalX (Thompson et al. 1997) and the phylogenetic analysis was performed with MEGA 4.1 software (Tamura et al. 
Table 4. Sequenced viral haemorrhagic septicaemia virus (VHSV) isolates from the present study and reference VHSV isolates used in the sequence comparisons

\begin{tabular}{|c|c|c|c|c|}
\hline VHSV isolate & Host & Location and year of isolation & Genotype & GenBank accession number \\
\hline Fi08.50RT & Rainbow trout & Finland 2008, present study & Id & MF176925 \\
\hline Fi06.59RT & Rainbow trout & Finland 2006, present study & Id & MF176926 \\
\hline Fi06.108RT & Rainbow trout & Finland 2006, present study & Id & MF176927 \\
\hline Fi08.22WF & Whitefish & Finland 2008, present study & Id & MF176928 \\
\hline Fi08.23WF & Whitefish & Finland 2008, present study & Id & MF176929 \\
\hline Fi08.24WF & Whitefish & Finland 2008, present study & Id & MF176930 \\
\hline FiA02a.01 & Rainbow trout & Finland 2001 & Id & AM086358 \\
\hline Fi19.04 & Rainbow trout & Finland 2004 & Id & AM086383 \\
\hline Hededam & Rainbow trout & Denmark 1972 & I & Z93412 \\
\hline Fi13 F1 & Rainbow trout & Germany 1998 & I & Y18263 \\
\hline DK 1p52 & Sprat & Baltic Sea 1996 & II & AY546576 \\
\hline DK 1p53 & Herring & Baltic Sea 1996 & II & AY546577 \\
\hline FR L59X & Eel & France 1987 & III & AY546618 \\
\hline DK 4p168 & Herring & Skagerrak 1997 & III & AY546582 \\
\hline US Makah & Coho salmon & Washington, USA, 1988 & IV & $\mathrm{U} 28747$ \\
\hline JP KRRV9822 & Japanese flounder & Japan 2000 & IV & AB179621 \\
\hline
\end{tabular}

2007). The percentage identities between paired nucleotide sequences were calculated with Megalign (DNASTAR).

\section{Statistical analysis}

The $95 \%$ confidence intervals for observed proportions were calculated with the EpiTools calculators (Sergeant 2016) using Jeffrey's method (Brown et al. 2001). The median prevalence estimate (\%) was calculated using R (R Core Team 2016).

\section{RESULTS}

\section{Virus detection from wild fish}

A total of 1636 wild fish, representing 17 different fish species, were caught and sampled (Table 1). All samples tested negative by virus isolation but 4 samples gave a weak signal with qRT-PCR $\left(C_{t}>36\right)$. These samples were negative for VHSV positivestranded RNA products, indicating that virus replication had not occurred in the tested fish at the time of sampling. Although no infected fish were detected, chance may have contributed to this non-detection, especially in those species with only few fish caught, as can be seen from the 95\% confidence intervals that provide estimates of true prevalence ranges, assuming a perfect test (Table 1). The median prevalence estimates show that the true prevalence would be closer to zero than the upper confidence limit.

\section{Infection trial in field conditions}

A clinical outbreak of VHS was diagnosed in the rainbow trout on the farm 5 wk before the trial started, and mortalities due to VHSV occurred as long as the diseased rainbow trout population was present in the farm. All rainbow trout in the farm were moved to a nearby summer farming site $14 \mathrm{~d}$ after the infection trial started, and only the test cages were left on the farm. Whitefish were the only species in the infection trial infected by VHSV. The infection was detected in only 1 of the 3 parallel groups of whitefish, from samples collected on Days 10 and 14. The virus was not isolated on Day 10, but qRT-PCR gave weak positive signals in all tissue samples from this group. On Day 14, VHSV was detected from all tissues tested with all 4 methods used (Table 2). The positive result of the strand-specific qRT-PCR method proved that VHSV replicated in whitefish and was not a contamination from the environment. Additionally, a sprivivirus was isolated from all fish species in this infection trial (Table 2). Spriviviruses grow in the same cell cultures as those used for VHSV isolation and were confirmed by sequencing (Holopainen et al. 2017).

The control groups outside the VHS restriction area were all negative for VHSV and sprivivirus.

\section{Sequencing of isolated VHS viruses}

The G gene of VHSV from the farmed rainbow trout and the whitefish from the infection trial was 
sequenced and compared with $\mathrm{G}$ gene sequences of some Finnish and other VHSV isolates belonging to genotypes I-IV (Table 4, Fig. S1 in supplement at www.int-res.com/articles/suppl/d131p187_supp.pdf). Pairwise sequence comparisons showed that the rainbow trout and whitefish isolates of the present study (GenBank accession numbers MF176925MF176930) were most closely related to the Finnish rainbow trout genotype Id isolates from the Province of Åland isolated during the years 2001 and 2004 (Raja-Halli et al. 2006). The nucleotide identity between these isolates was $99.4-99.9 \%$. The G gene sequence identity between VHSV isolates from rainbow trout and whitefish of the infection trial and VHSV isolates belonging to genotypes III and IV were approximately $91 \%$ and $86 \%$, respectively. The 3 whitefish isolates from the infection trial and the rainbow trout Fi08.50RT originating from the same farm and year (2008) as the whitefish isolates were $100 \%$ identical to each other. These results indicate that whitefish in the infection trial were infected with the same VHS virus that was present in the farmed rainbow trout on the farm where the infection trial was performed.

\section{DISCUSSION}

Wild fish are not a likely source for the reappearing VHS outbreaks in the Finnish brackish-water fish farms. Although wild fish have been reported to be carriers of several different VHSV genotypes in the North Sea and the Baltic Sea (Skall et al. 2005), there are no reports indicating that VHSV Id in wild fish is connected with the clinical disease in farmed fish. The number of different fish species in close vicinity of the fish farms in the present study was high, but the number of individuals of each fish species varied from only a few individuals for species such as pike or sea trout to thousands for species such as perch, roach or three-spined sticklebacks. In our study, the observed prevalence of VHSV was zero in 17 different tested wild fish species that were screened during several years in the vicinity of 2 infected fish farms. The results indicated that if the screening missed the infection in these species caught in quite high numbers (see Table 1), the prevalence would have been no more than $4 \%$ (the upper limit of the $95 \%$ confidence limit is lower than that). The sample size was low for defining the possible prevalence range of some species and the results are inconclusive. The fish species that were caught in small numbers are species for which presence on the farm or in the vicinity was apparently low, and they comprise less than $5 \%$ of all fish analysed. The low numbers of these species on the fish farm are likely representative of the actual numbers present, as fish farms are not the normal habitat for these species. Organ pools from fish species caught in low numbers contained organs from fewer individuals than those from species caught in high numbers, reducing the possible effect of virus dilution.

There are several facts that support our result of the minor role of wild fish in VHSV transmission. The farms where the wild fish were caught experienced several outbreaks of VHS in their fish during the study. If the wild fish had a major role, one would expect to find clear positive signals with qRT-PCR from the tested wild fish as VHSV was present in the environment on several of the sampling occasions. In Finland, there have been 2 other VHS restriction areas, in similar farms producing rainbow trout, where the viruses were successfully eradicated at the first attempt. These areas have the same kind of wild fish populations as the farms in the study area in the Province of Åland. It is possible that some of the tested fish species could be transient carriers of the virus and therefore were not caught using the screening method. More studies on the prevalence of VHS in wild fish are needed, as all fishing methods have species and size selectivities that may bias the results.

Two wild fish species, roach and perch, which are among the most common species living in the vicinity of brackish-water fish farms, were also exposed to a natural VHSV infection under stressful conditions in small cages, but no VHSV was isolated from these fish. On the contrary, farmed whitefish kept in the same conditions as roach and perch were infected by VHSV Id. The virus was detected for a short period, but no mortalities were recorded. It is possible that whitefish are transient carriers of VHSV as the virus was not detected in the whitefish groups after the infected rainbow trout were moved away from the farm. According to the Finnish authorities, VHSV has only been isolated once from farmed whitefish in the VHS restriction area (P. Vennerström unpubl. data).

A sprivivirus was isolated from all tested fish species in the infection trial, but it was not associated with mortalities. The skin of the fish infected with sprivivirus turned reddish in colour as a result of congestion in the skin, but internal pathology was not detected in these fish. These findings were not studied further in this trial. Sprivivirus has occasionally been isolated from farmed sea trout in the study area in connection with bacterial fish diseases during the summertime, when water temperatures are greater 
than $15^{\circ} \mathrm{C}$ (R. Holopainen, pers. comm.). Sprivivirus seems to be an endemic virus in the study area and it is not clear whether this virus could be a predisposing factor of the VHSV outbreaks or influence on screening of VHSV. Spriviviruses have not been reported from the other 2 successfully eradicated restriction zones of VHS.

Whitefish could be a potential source of the recurring VHS outbreaks in the VHS restriction area, as they were either farmed in the same farms as rainbow trout or have close contact with these farms. Whitefish are brought as juveniles to the farms and are farmed for 1 to $2 \mathrm{yr}$ in the brackish-water fish farms. Whitefish is a native species of the Baltic Sea, where VHSV is endemic. Rainbow trout, on the other hand, is not a native species and may therefore be more susceptible to VHSV infection than native Baltic fish species. This is supported by the fact that mortality caused by VHSV Id in Finnish whitefish has never been reported, although whitefish are also screened repeatedly for VHSV according to regulations. In our study, no wild whitefish were caught during the wild fish screening, but according to our infection trial with farmed juvenile whitefish, we found that they were infected by VHSV and that replication of the virus occurred for a short time period in their organs. It seems that whitefish are not sensitive to VHSV Id infections and that they may clear out the virus infection without developing notable clinical signs. This result is also supported by the fact that no mortalities caused by VHSV in farmed white fish have been reported during more than $10 \mathrm{yr}$ of disease monitoring of farmed whitefish in the VHSV-infected fish farms. Since whitefish may be infected by VHSV Id and the virus can replicate in this fish species, whitefish kept close to VHSVpositive rainbow trout populations may give the virus an opportunity to jump to whitefish and survive longer in the area. It also gives the virus the opportunity to adapt and become more virulent to whitefish, and perhaps even to other native species in the Baltic Sea. Danish scientists have reported that European whitefish are susceptible to infection with some rainbow-trout-adapted VHSV types (Skall et al. 2004). However, VHSV was not detected in wild-caught whitefish in a river system close to VHS-positive fish farms (Skall et al. 2004).

On the west coast of Sweden, VHSV was isolated from herring caught close to rainbow trout farms. On these farms, VHSV genotype Ib had caused several outbreaks on the farms, although the farms had been repeatedly emptied of fish, including removal and disinfection of all farming equipment. The herring isolates were almost identical to the genotype that was causing VHS in the farmed rainbow trout. It was assumed that the herring on their spawning migration brought the infection repeatedly to the farm and eventually made rainbow trout farming in that area impossible (Nordblom \& Norell 2000, Jansson \& Vennerström 2014). Another example of wild fish being the source of VHS outbreaks is from Norway, where VHSV genotype III was isolated from 4 sea-reared rainbow trout farms in Storfjorden in 2007 (Dale et al. 2009). Although VHSV III had earlier been isolated from several wild marine fish species and infection trials had proven rainbow trout not to be sensitive to genotype III strains, mortality was recorded in these outbreaks. Sequence analyses of the isolated VHSV III strain in Norway revealed it to be unique. According to infection trials, rainbow trout was reported to be susceptible to this new genotype III strain (Dale et al. 2009). The source of the infection is not clear, but these VHSV-positive farms had close connections to cod Gadus morhua and saithe Pollachius virens farming, where raw processed fish of marine origin are used for feed. Containers of dead farmed rainbow trout, cod and saithe from other sites were stored close to the primary infected site (Dale et al. 2009).

\section{CONCLUSIONS}

According to our study, wild fish living freely in the fish farming area do not seem to threaten the farmed fish with respect to VHSV Id infection in Finland. Farmed whitefish as a native species was a likely source of the recurring VHS outbreaks in Finnish brackish-water food fish farms, as they were infected but cleared out the infection. Wild fish may function as carriers between closely situated farms. Therefore, it is important to perform stamping out of infected fish farms and decrease the infection pressure and adaptation possibilities in other fish species.

Acknowledgements. This work was funded by the Finnish Ministry of Agriculture and Forestry, Dno 4876/501/2005, project 310159. We thank Perttu Koski and Satu ViljamaaDirks for critical reading of the manuscript. We thank Riikka Holopainen for virus typing of Sprivivirus.

\section{LITERATURE CITED}

Ammayappan A, Vakharia VN (2009) Molecular characterization of the Great Lakes viral hemorrhagic septicemia virus (VHSV) isolate from USA. Virol J 6:171

Bain MB, Cornwell ER, Hope KM, Eckerlin GE and others (2010) Distribution of an invasive aquatic pathogen (viral 
hemorrhagic septicemia virus) in the Great Lakes and its relationship to shipping. PLOS ONE 5:e10156

Brown LD, Cai TT, DasGupta A (2001) Interval estimation for a binomial proportion. Stat Sci 16:101-117

Chico V, Gomez N, Estepa A, Perez L (2006) Rapid detection and quantitation of viral hemorrhagic septicemia virus in experimentally challenged rainbow trout by real-time RT-PCR. J Virol Methods 132:154-159

Cuenca A, Vendramin N, Sigurðardóttir H, Olesen NJ, Guðmundsdóttir S (2017) New viral haemorrhagic septicaemia (VHS) virus subtype in Europe. Report 21st Annual Workshop of the European Union National Reference Laboratories for Fish Diseases, Kgs. Lyngby. www.medaid-h2020.eu/wp-content/uploads/2018/07/ 22nd-AW-report-2018.pdf

Dale OB, Orpetveit I, Lyngstad TM, Kahns S, Skall HF, Olesen NJ, Dannevig BH (2009) Outbreak of viral haemorrhagic septicaemia (VHS) in seawater-farmed rainbow trout in Norway caused by VHS virus Genotype III. Dis Aquat Org 85:93-103

Dixon P (1999) VHSV came from the marine environment: clues from the literature, or just red herrings? Bull Eur Assoc Fish Pathol 19:60-65

EC (European Commission) (2001) 2001/183/EC(2001) Commission Decision of 22 February 2001 laying down the sampling plans and diagnostic methods for the detection and confirmation of certain fish diseases and repealing Decision 92/532/EEC

Einer-Jensen K, Ahrens P, Forsberg R, Lorenzen N (2004) Evolution of the fish rhabdovirus viral haemorrhagic septicaemia virus. J Gen Virol 85:1167-1179

Einer-Jensen K, Ahrens P, Lorenzen N (2005) Parallel phylogenetic analyses using the N, G or Nv gene from a fixed group of VHSV isolates reveal the same overall genetic typing. Dis Aquat Org 67:39-45

Elsayed E, Faisal M, Thomas M, Whelan G, Batts W, Winton $\mathrm{J}$ (2006) Isolation of viral haemorrhagic septicaemia virus from muskellunge, Esox masquinongy (Mitchill), in Lake St Clair, Michigan, USA reveals a new sublineage of the North American genotype. J Fish Dis 29:611-619

Emmenegger EJ, Moon CH, Hershberger PK, Kurath G (2013) Virulence of viral hemorrhagic septicemia virus (VHSV) genotypes Ia, IVa, IVb, and IVc in five fish species. Dis Aquat Org 107:99-111

Finnish Food Safety Authority (2010) Animal diseases in Finland 2010. Finnish Food Safety Authority. https:// www.evira.fi/globalassets/tietoa-evirasta/julkaisut/julkai susarjat/elaimet/elaintaudit_suomessa_2010_210312.pdf

Gadd T, Jakava-Viljanen M, Einer-Jensen K, Ariel E, Koski P, Sihvonen L (2010) Viral haemorrhagic septicaemia virus (VHSV) genotype II isolated from European river lamprey Lampetra fluviatilis in Finland during surveillance from 1999 to 2008. Dis Aquat Org 88:189-198

Gadd T, Jakava-Viljanen M, Tapiovaara H, Koski P, Sihvonen L (2011) Epidemiological aspects of viral haemorrhagic septicaemia virus genotype II isolated from Baltic herring, Clupea harengus membras L. J Fish Dis 34:517-529

Gagné N, Mackinnon AM, Boston L, Souter B, Cook-Versloot M, Griffiths S, Olivier G (2007) Isolation of viral haemorrhagic septicaemia virus from mummichog, stickleback, striped bass and brown trout in eastern Canada. J Fish Dis 30:213-223

Groocock GH, Getchell RG, Wooster GA, Britt KL and others (2007) Detection of viral hemorrhagic septicemia in round gobies in New York State (USA) waters of Lake Ontario and the St. Lawrence River. Dis Aquat Org 76: $187-192$

Holopainen R, Vennerström P, Viljamaa-Dirks S, Lindh E, Smura T, Gadd T (2017) Genomic characterisation of rhabdoviruses isolated from wild and farmed fish in Finland. In: Vidovsky M, Böszörmeyi K, Kaján G (eds) Proc 10th International Symposium on Viruses of Lower Vertebrates (Book of Abstracts). Hungarian Academy of Science, Budapest

Ito T, Olesen NJ (2013) Susceptibility of various Japanese freshwater fish species to an isolate of viral haemorrhagic septicaemia virus (VHSV) genotype IVb. Dis Aquat Org 107:1-8

Jansson E, Vennerström P (2014) Infectious diseases in cold water fish in marine and brackish waters. In: Woo PTK, Bruno DW (ed) Diseases and disorders in finfish in cage culture, 2nd edn. CAB International, London, p 17-19

Kim R, Faisal M (2010) Experimental studies confirm the wide host range of the Great Lakes viral haemorrhagic septicaemia virus genotype IVb. J Fish Dis 33:83-88

Kumsden JS, Morrison B, Yason C, Russell S and others (2007) Mortality event in freshwater drum Aplodinotus grunniens from Lake Ontario, Canada, associated with viral haemorrhagic septicemia virus, Type IV. Dis Aquat Org 76:99-111

* Marty GD, Freiberg EF, Meyers TR, Wilcock J, Farver TB, Hinton DE (1998) Viral hemorrhagic septicemia virus, Ichthyophonus hoferi, and other causes of morbidity in Pacific herring Clupea pallasi spawning in Prince William Sound, Alaska, USA. Dis Aquat Org 32:15-40

Meyers TR, Winton JR (1995) Viral hemorrhagic septicemia virus in North America. Annu Rev Fish Dis 5:3-24

* Meyers TR, Short S, Lipson K (1999) Isolation of the North American strain of viral hemorrhagic septicemia virus (VHSV) associated with epizootic mortality in two new host species of Alaskan marine fish. Dis Aquat Org 38: 81-86

*Mortensen HF, Heuer OE, Lorenzen N, Otte L, Olesen NJ (1999) Isolation of viral haemorrhagic septicaemia virus (VHSV) from wild marine fish species in the Baltic Sea, Kattegat, Skagerrak and the North Sea. Virus Res 63: 95-106

*Nishizawa T, Iida H, Takano R, Isshiki T, Nakajima K, Muroga K (2002) Genetic relatedness among Japanese, American and European isolates of viral hemorrhagic septicemia virus (VHSV) based on partial G and P genes. Dis Aquat Org 48:143-148

Nordblom B, Norell AW (2000) Report on an outbreak of VHS (viral haemorrhagic septicaemia) in farmed fish in Sweden. Report for the Standing Veterinary Committee, Swedish Board of Agriculture, Department for Animal Production and Health, Stockholm

OIE (World Organisation for Animal Health) (2017) Manual of diagnostic tests for aquatic animals. www.oie.int/ international-standard-setting/aquatic-manual/accessonline/.

* Olesen NJ, Vestergård Jørgensen PE (1992) Comparative susceptibility of three fish cell lines to Egtved virus, the virus of viral haemorrhagic septicaemia (VHS). Dis Aquat Org 12:235-237

* Pierce LR, Stepien CA (2012) Evolution and biogeography of an emerging quasispecies: diversity patterns of the fish viral hemorrhagic septicemia virus (VHSv). Mol Phylogenet Evol 63:327-341 
Purcell MK, Hart SA, Kurath G, Winton JR (2006) Strandspecific, real-time RT-PCR assays for quantification of genomic and positive-sense RNAs of the fish rhabdovirus, infectious hematopoietic necrosis virus. J Virol Methods 132:18-24

R Core Team (2016) R: a language and environment for statistical computing. R Foundation for Statistical Computing, Vienna. https://www.R-project.org/

Raja-Halli M, Vehmas TK, Rimaila-Parnanen E, Sainmaa S, Skall HF, Olesen NJ, Tapiovaara H (2006) Viral haemorrhagic septicaemia (VHS) outbreaks in Finnish rainbow trout farms. Dis Aquat Org 72:201-211

Schutze H, Mundt E, Mettenleiter TC (1999) Complete genomic sequence of viral hemorrhagic septicemia virus, a fish rhabdovirus. Virus Genes 19:59-65

Sergeant E (2016) Epitools epidemiological calculators. AusVet Animal Health Services and Australian Biosecurity Cooperative Research Centre for Emerging Infectious Disease. Available at http://epitools.ausvet.com.au.

Skall HF, Kjaer TE, Olesen NJ (2004) Investigation of wild caught whitefish, Coregonus lavaretus (L.), for infection with viral haemorrhagic septicaemia virus (VHSV) and experimental challenge of whitefish with VHSV. J Fish Dis 27:401-408

Skall HF, Olesen NJ, Mellergaard S (2005) Viral haemorrhagic septicaemia virus in marine fish and its implications for fish farming — a review. J Fish Dis 28:509-529

Editorial responsibility: Stephen Feist, Weymouth, UK
Snow M, Cunningham CO, Melvin WT, Kurath G (1999) Analysis of the nucleoprotein gene identifies distinct lineages of viral haemorrhagic septicaemia virus within the European marine environment. Virus Res 63:35-44

Stone DM, Way K, Dixon PF (1997) Nucleotide sequence of the glycoprotein gene of viral haemorrhagic septicaemia (VHS) viruses from different geographical areas: a link between VHS in farmed fish species and viruses isolated from North Sea cod (Gadus morhua L.). J Gen Virol 78: 1319-1326

* Tamura K, Dudley J, Nei M, Kumar S (2007) MEGA4: Molecular Evolutionary Genetics Analysis (MEGA) software version 4.0. Mol Biol Evol 24:1596-1599

Thiéry R, de Boisséson C, Jeffroy J, Castric J, de Kinkelin P, Benmansour A (2002) Phylogenetic analysis of viral haemorrhagic septicaemia virus (VHSV) isolates from France (1971-1999). Dis Aquat Org 52:29-37

* Thompson JD, Gibson TJ, Plewniak F, Jeanmougin F, Higgins DG (1997) The CLUSTAL_X windows interface: flexible strategies for multiple sequence alignment aided by quality analysis tools. Nucleic Acids Res 25: 4876-4882

*Vennerström P, Välimäki E, Lyytikäinen T, Hautaniemi M, Vidgren G, Koski P, Virtala AM (2017) Viral haemorrhagic septicaemia virus (VHSV Id) infections are detected more consistently using syndromic vs. active surveillance. Dis Aquat Org 126:111-123

Submitted: April 20, 2018; Accepted: September 25, 2018 Proofs received from author(s): November 15, 2018 